\title{
The specific leaf area of forest species subjected to different degrees of shading did not differ when detached and full leaflets were compared
}

\section{Folhas compostas de espécies florestais apresentam a mesma área foliar específica com folíolos destacados ou com folhas completas sob sombreamento}

\author{
Jacqueline Lucia Guimarães ${ }^{1}$; Cristina Moll Hüther ${ }^{2 *}$; Ramonn Diego Barros de \\ Almeida $^{1}$; Lilian Thurler Nogueira ${ }^{1}$; Luiza Ferreira de Carvalho ${ }^{3}$; Junior Borella ${ }^{4}$; \\ Thelma de Barros Machado ${ }^{5}$ Carlos Rodrigues Pereira ${ }^{5}$
}

\section{Highlights:}

Leaf area assessment methods produced similar results in forest species.

Total leaf area measurements in plants with compound leaves are representative.

A comparison leaf area analysis methods used to assess forest species was performed.

\begin{abstract}
Studies of forest species under different environmental conditions are essential for enhancing our understanding of plant-environment relationships. Different light conditions interfere with the production of seedlings within forests, and this interference can be verified by assessing leaf area. However, several species have leaf compound that often contain numerous leaflets, which makes the direct measurement of leaf area difficult. This leads researchers to question whether these types of leaves should be separated for analysis or measured whole. Thus, the aim of this study was to analyse specific leaf area in whole leaves and detached leaflets of six forest species subjected to different levels of shading. The forest species assessed all produced compound leaves and included Schinus terebinthifolius Raddi (aroeira), Schinopsis brasiliensis Engl. (braúna), Dalbergia nigra (Vell.) Fr. All. ex Benth. (jacaranda-da-bahia), Chorisia speciosa A. St.-Hil (paineira), Caesalpinia peltophoroides Benth (sibipiruna) and Plathymenia reticulata Benth (vinhático). Each species was subjected to six different degrees of shading: $0 \%$ (full sun); $20 ; 40 ; 60 ; 80$ and $90 \%$. Sombrite netting was used to shade plants. The analysis of the specific leaf area was performed using two different methods, which included the analysis of separate leaflets and whole leaves. To analyse leaflet area,50 leaflets per plant were assessed three times, and six plants
\end{abstract}

\footnotetext{
1 Discentes do Curso de Mestrado do Programa de Pós-Graduação em Engenharia de Biossistemas, Departamento de Engenharia Agrícola e do Meio Ambiente, Universidade Federal Fluminense, UFF, Niterói, RJ, Brasil. E-mail: jaclucmath@gmail.com; ramonnbarros@id.uff.br; lilianthurler@id.uff.br

2 Pós-Doutoranda do Programa de Pós-Graduação em Engenharia de Biossistemas, Departamento de Engenharia Agrícola e do Meio Ambiente, UFF, Niterói, RJ, Brasil. E-mail: cristinahuther@yahoo.com.br

3 Discente do Curso de Graduação em Engenharia Agrícola e Ambiental e Iniciação Científica do Programa de Pós-Graduação em Engenharia de Biossistemas, Departamento de Engenharia Agrícola e do Meio Ambiente, UFF, Niterói, RJ, Brasil. E-mail: luizafc@id.uff.br

4 Prof. Dr., Instituto de Ciências Biológicas, Universidade Federal do Rio Grande, FURG, Rio Grande, RS, Brasil. E-mail: borellaj@gmail.com

5 Profs. Drs., Programa de Pós-Graduação em Engenharia de Biossistemas, Departamento de Engenharia Agrícola e do Meio Ambiente, UFF, Niterói, RJ, Brasil. E-mail: thelma_machado@id.uff.br; crpereira@id.uff.br
}

* Author for correspondence 
per treatment were assessed. To assess whole leaves, data were obtained from the whole leaves of six plants per treatment. This process was repeated for all aforementioned species. Data obtained from both analysis methods indicated that all species assessed were similarly affected by shade, and leaf area varied according to the level of shading. This similarity of data demonstrates that, for these species, it is not necessary to use complex methods to obtain specific leaf area measurements. Thus, determining specific leaf by measuring the entire leaf provides results that did not statistically differ from those obtained by measuring individual leaflets.

Key words: Atlantic forest. Compound leaf. Ecophysiology. Growth. Reforestation.

\section{Resumo}

Estudos com espécies florestais, em diferentes condições ambientais são essenciais para o entendimento da relação planta-ambiente. Diferentes condições de luminosidade podem interferir na produção de mudas florestais e o reflexo dessa interferência pode ser verificado pela análise da área foliar. No entanto, muitas espécies apresentam folhas compostas, sendo muitas vezes com inúmeros folíolos, o que dificulta as análises com mensuração direta da área foliar, proporcionando dúvidas durante a análise, se devem ser separados para análise ou mensurados com a folha inteira. Assim, o objetivo desse estudo foi analisar a área foliar específica em folhas inteiras e folíolos destacados de folhas compostas de seis espécies florestais submetidas à diferentes níveis de sombreamento. As espécies florestais utilizadas foram Schinus terebinthifolius Raddi (aroeira), Schinopsis brasiliensis Engl. (braúna), Dalbergia nigra (Vell.) Fr. All. ex Benth. (jacarandá-da-bahia), Chorisia speciosa A.St.-Hil (paineira), Caesalpinia peltophoroides Benth (sibipiruna) e Plathymenia reticulata Benth (vinhático), todas com folhas compostas. Cada espécie foi submetida a seis tratamentos de sombreamento: $0 \%$ (pleno sol); 20 ; 40; 60; 80 e 90\%, com a utilização de "sombrites" para os tratamentos sombreados. A análise da área foliar específica foi realizada de duas maneiras: folíolos separados e folha inteira. Para a análise dos folíolos esses foram obtidos de três medidas (repetições) de 50 folíolos por planta, realizada em seis plantas por tratamento. Para a análise da folha inteira os dados foram obtidos de folhas inteiras de seis plantas por tratamento. Esse processo se repetiu em todas as espécies supramencionadas. Para todas as espécies, os dados indicaram um padrão de resposta semelhante em ambos os métodos de análise, variando de acordo com os níveis de sombreamento. Essa similaridade dos dados demonstra que, para essas espécies, não é necessário a utilização de métodos muito complexos para a obtenção da área foliar específica. Assim, a obtenção da área foliar específica utilizando a folha inteira fornece resultados estatisticamente iguais em relação àquela obtida utilizando somente folíolos.

Palavras-chave: Crescimento. Ecofisiologia. Folha Composta. Mata Atlântica. Reflorestamento.

\section{Introduction}

The Atlantic Forest is a natural resource with value that is derived from its chemical, biological and genetic potential (Oliveira et al., 2012; Meio Ambiente - Instituto de Química - Universidade Federal do Rio de Janeiro [Meioambiente/Iq/ Ufrj], 2016). Exploitation of the forest has put flora and fauna at risk (Gris \& Temponi, 2017), and fragmentation and habitat loss threaten the maintenance of biodiversity (Chazdon \& Uriarte, 2016). Natural regeneration or reforestation is considered an efficient tool, which can be used to stabilize or accelerate the recovery of dismantled areas (Ottermanns et al., 2011).

Studies of forest species from the Atlantic Forest biome that assess effects of different environmental conditions are important for the verification and monitoring growth of native species, enhancing production of quality seedlings, and generating fundamental information to regulate the forestry activity, which includes the implementation of conservation and reforestation programs (Monteiro \& Ramos, 1997; Dutra, Grazziotti, Santana, \& Massad, 2012; Roweder, Nascimento, \& Silva, 2015). 
To enhance the sustainability and viability of forest species is important to improve the reproductive capacity of species. In this context, studying the effects of different types of shade is useful for cultivating forest species, especially within nurseries dedicated to seedling production. Lighting requirements and the conversion efficiency of absorbed light energy can be assessed by measuring available leaf area (Câmara \& Endres, 2008; Permanhani, Vasconcellos, Souza, \& Martelleto, 2014).

Studies that evaluate the leaf area in plants under different environmental conditions are essential for enhancing our understanding plant-environment relationships (Moraes, Santos, Zeizer, \& Krupek, 2013). Several studies implemented methods to estimate leaf area (Gao, Van der Heijden, Eveleens, \& Marcelis, 2012; Liang, Kirk, \& Greene, 2018; Dong et al., 2019), and others have used empirical models that facilitate monitoring species growth (Wang, Jin, Shi, \& Liu, 2019).

With regard toleafarea assessments are performed in the laboratory. However, the effectiveness of the methodology used to determine leaf area has been questioned. Concerns regarding the reliability of leaf area measurements are especially relevant when forest species with compound leaves containing leaflets are assessed, because researchers have not determined if measurements should be carried out using entire leaves, or if leaflets must be separated from leaves before measurements are performed.

Thus, the reliability of data obtained using both methods must be verified, and leaf area measurements using both whole leaves and leaflets of forest species should be compared. This assessment should determine whether leaf area measurements in plants with compound leaves are reliable regardless of whether detached leaflets or the entire leaves are assessed, which will have implications regarding the feasibility leaf area assessments. Thus, the aim of this study was to compare specific leaf area (SLA) determined for six different forest species that were subjected to different levels of shading by performing leaf area measurements of both whole and detached leaflets of compound leaves.

\section{Material and Methods}

The experiment was carried out in the experimental area "Terrace" of Embrapa Agrobiologia, Brazilian Agricultural Research Corporation, in Seropédica city (22 $45^{\circ} 18.33^{\prime}$ 'S; $43^{\circ} 39^{\prime} 58.37^{\prime \prime} W ; 28 \mathrm{~m}$ elevation), in the State of Rio de Janeiro. Six native forest species (Atlantic Forest) including Schinus terebinthifolius Raddi (aroeira), Schinopsis brasiliensis Engl. (braúna), Dalbergia nigra (Vell.) Fr. All. ex Benth. (jacarandada-bahia), Chorisia speciosa A.St.-Hil (paineira), Caesalpinia peltophoroides Benth (sibipiruna) and Plathymenia reticulata Benth (vinhático) were cultivated in greenhouses and subjected to different levels of shading. The experimental design was fully randomized and six replicates were assessed.

Seed sowing was performed using a seedbed composed of washed sand substrate, and 500 seeds per species were sown. After germination, when seedlings reached a height of $10 \mathrm{~cm}$, seedlings were transplanted into $25 \times 20 \mathrm{~cm}$ plastic bags $25 \times 20$ $\mathrm{cm}$ that contained a 1:1:1 ratio of clay soil, washed sand and tanned bovine manure substrate.

The greenhouses were $2.5 \times 6 \times 10$ m wooden structures that were covered using black mash screens to generate the following levels of shading: 20, 40, 60, 80 and 90\%. Growth under full sunlight (control) was also assessed. Air temperature, photosynthetically active radiation (PAR) and relative humidity data were obtained via automatic WatchDog 2550 weather stations (Spectrum Weather), which were installed in each environment. Each shade level was measured with using a Model LP PAR 80 ceptometre (AccuPAR). All six species were grown together in greenhouses, and were subjected to specific levels of shading or full sunlight. 
Three hundred five days post-sowing, six plants of each species were harvested per treatment. Leaves of sampled plants of each species were measured using two different methods (whole compound leaves and detached leaflets). Direct measurements were performed using a LI-3100C Area Meter instrument (LICOR, Inc). In addition, leaf dry matter mass was obtained after leaves were dried in an oven until a constant mass was determined ( $\sim 72$ hrs at $65^{\circ} \mathrm{C} \pm 5$ ) using a precision analytical balance.

To determine detached leaflet area, three measurements (repetitions) of 50 leaflets per plant (collected randomly from each plant) were performed on six plants per treatment. The total leaf area measurements determined for 50 leaflets was divided by 50 to generate mean leaflet area, which was divided by average leaflet dry matter mass. Entire leaf area was determined by measuring the leaf area of six plants per treatment.

SLA was obtained by dividing the leaf area by the leaf dry matter mass. The data were submitted to analysis of variance ( $5 \%$ significance), and adjusted via regression analysis (5\%) of shading levels for all species. Differences in SLA were assessed using the Tukey test (5\%) and Assistat software (7.6 beta).

\section{Results and Discussion}

SLAs of whole and detached leaflets were the same for all forest species analyzed, and leaf size varied only according to shading level. We recommended using entire compound leaves to perform measurements without detaching leaflets, since no statistical difference between the two forms were observed when measurements were performed direct measurement reading mode. Throughout the experiment, photosynthetically active radiation decreased as shading levels increased. Further, relative humidity, air temperature, dew point temperature and precipitation levels did not vary in greenhouses providing different levels of shade, and species were cultivated under appropriate conditions (data not shown).
The results of the analysis of Schinus terebinthifolius (aroeira) are shown in Figure 1A. Data revealed that even when plants were subjected to $60 \%$ shade, leaves grew normally and specific area remained unaffected. The shading levels of 80 and $90 \%$ resulted in increased SLA, and new and expanded leaflets were produced. These findings indicated that very high levels of shading affected the growth of the species. According to Scalon, Sacalon and Masetto (2012), luminosity can greatly influence the leaf area and leaf development. In the study, researchers determined that leaf growth of aroeira seedlings was greatest when subjected to $0 \%$ of shading (full sunlight). In accordance with results of this study, Leite (2002) reported that aroeira seedlings are sensitive to high levels of light and recommended that the species should be planted under shady conditions.

The SLA of whole leaves increased $78.37 \mathrm{~cm}^{2} \mathrm{~g}$ ${ }^{1}$ when plants were subjected to increased levels of shading ( $60 \%$ to $90 \%$ shade). However, when analyzing increases in SLA in plants exposed to $0 \%$ and $60 \%$ shade, just a $70.29 \mathrm{~cm}^{2} \mathrm{~g}^{-1}$ increase observed. When new leaflets, expanded leaflets and whole leaves were assessed separately, the SLAs of leaves subjected $90 \%$ shading relative to full sunlight increased 222.13; 263.18 and 248.66 $\mathrm{cm}^{2} \mathrm{~g}^{-1}$, respectively, which corresponded to 41 , 30 and $32 \%$ increases, respectively. When values determined using whole leaves and leaflets were compared, no statistical differences were observed for any level of shading (data not shown).

Since no difference between whole leaves and leaflets of aroeira were observed, an analysis SLA differences observed when plants were subjected to different levels of shading was performed. This analysis revealed that shading influenced SLA, and findings are included in Table 1. For aroeira, results showed that levels of shading between 20 and $40 \%$ did not affect SLA. Aroeira are pioneer species, therefore, they are expected to tolerate full sunlight treatment (Azevedo, Quirino, \& Bruno, 2015). Accordingly, plants subjected to $90 \%$ shade 
produced leaves with the greatest SLA values. According to Klich (2000), in areas exposed to increased levels of light, species tend to have small leaves to reduce potential negative effects of elevated transpiration rates and high ambient temperatures.
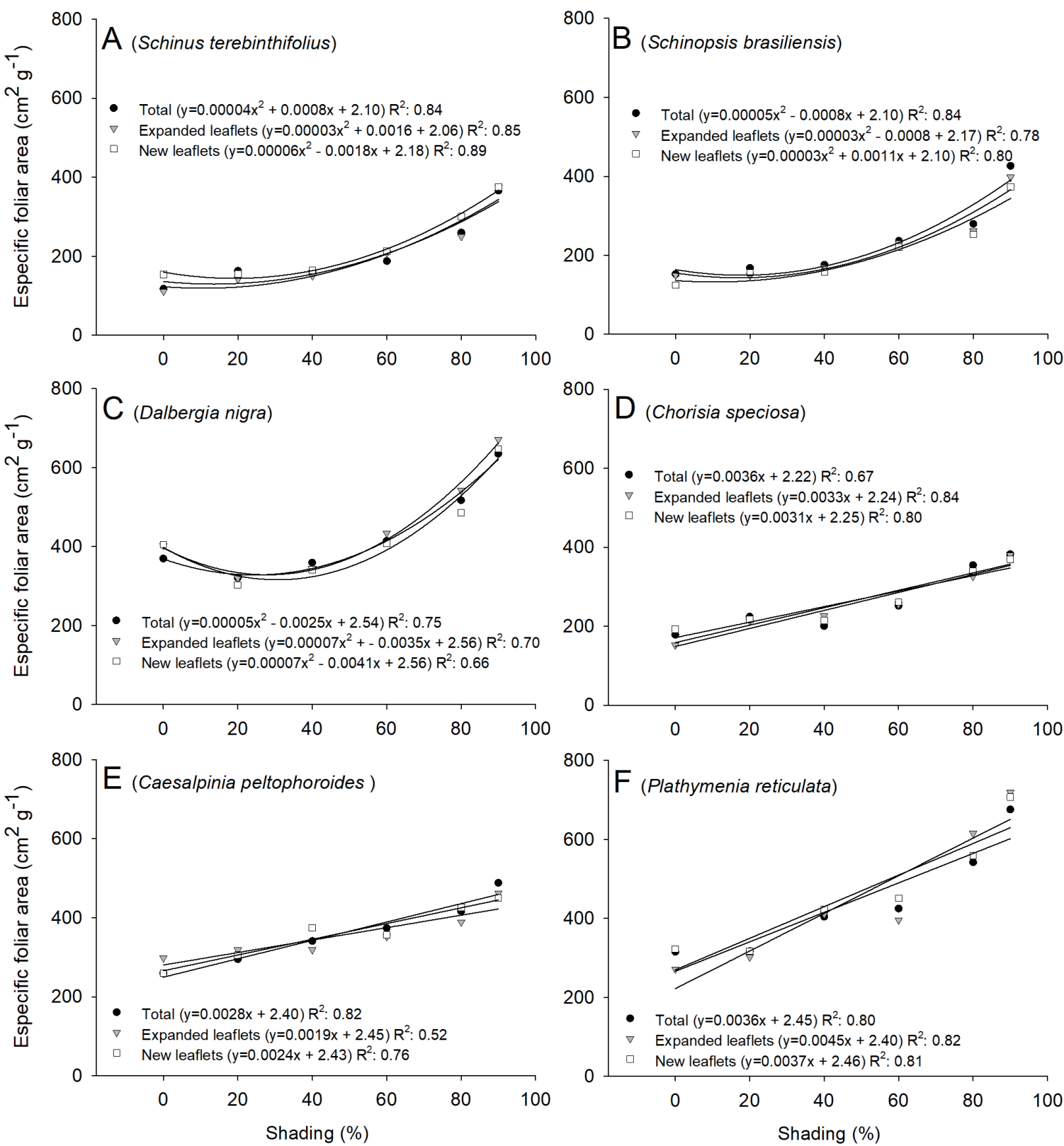

Figure 1. Specific Leaf Area of six forest species subjected to different shading levels $(0 ; 20 ; 40 ; 60 ; 80$ and 90\%). Aroeira: Schinus terebinthifolius Raddi (A); braúna: Schinopsis brasiliensis Engl. (B); jacaranda-dabahia: Dalbergia nigra (Vell.) Fr. All. ex Benth. (Ç); paineira: Chorisia speciosa A.St.-Hil (D); sibipiruna: Caesalpinia peltophoroides Benth (E); wine: Plathymenia reticulata Benth (F). The data (symbols) represents the mean adjusted via regression analysis $(5 \%)$ of shading levels for all species. 
The results determined from the assessment of Schinopsis brasiliensis Engl. (braúna) leaf growth are represented in Figure 1B. Data revealed that exposure to $0-40 \%$ shading resulted in similar SLA values, and increased SLA was observed in plants subjected 60,80 and $90 \%$ shade. In plants subjected to $90 \%$ shading, leaf area reached 373.66 $\mathrm{cm}^{2} \mathrm{~g}^{-1}$ for new leaflets, $397.81 \mathrm{~cm}^{2} \mathrm{~g}^{-1}$ for expanded leaflets and $426.51 \mathrm{~cm}^{2} \mathrm{~g}^{-1}$ for whole leaves. In plants subjected to full sunlight, the leaf area was determined to be $124.71,149.86$ and $152.35 \mathrm{~cm}^{2}$ $\mathrm{g}^{-1}$ for new leaflets, expanded leaflets, and whole leaves, respectively. Thus, an SLA increase of 33, 38 and $36 \%$, respectively, was observed. Plants exposed to $90 \%$ shading were determined to have the greatest SLA regardless of whether whole leaves, or new or expanded leaflets were measured. Further, differences between areas of expanded and new leaflets relative to that of whole leaves were not significant (data not shown).

Table 1

Averages of the specific leaf area (SLA) of six forest species subjected to different levels of shading

\begin{tabular}{lcccccc}
\hline \multirow{2}{*}{ SLA species } & \multicolumn{7}{c}{ Shading levels } \\
\cline { 2 - 7 } & $0 \%$ & $20 \%$ & $40 \%$ & $60 \%$ & $80 \%$ & $90 \%$ \\
\hline Schinus terebinthifolius & $127.40 \mathrm{~d}$ & $153.43 \mathrm{~d}$ & $158.49 \mathrm{~d}$ & $202.87 \mathrm{c}$ & $270.08 \mathrm{~b}$ & $372.06 \mathrm{a}$ \\
Schinopsis brasiliensis & $142.30 \mathrm{c}$ & $153.84 \mathrm{c}$ & $168.39 \mathrm{c}$ & $229.72 \mathrm{~b}$ & $264.99 \mathrm{~b}$ & $399.32 \mathrm{a}$ \\
Dalbergia nigra & $392.54 \mathrm{~cd}$ & $314.87 \mathrm{e}$ & $348.50 \mathrm{de}$ & $418.88 \mathrm{c}$ & $515.47 \mathrm{~b}$ & $651.43 \mathrm{a}$ \\
Chorisia speciosa & $185.15 \mathrm{e}$ & $217.94 \mathrm{~d}$ & $213.86 \mathrm{~d}$ & $256.03 \mathrm{c}$ & $340.17 \mathrm{~b}$ & $377.39 \mathrm{a}$ \\
Caesalpinia peltophoroides & $272.13 \mathrm{~b}$ & $306.16 \mathrm{a}$ & $344.61 \mathrm{~b}$ & $360.67 \mathrm{~b}$ & $410.40 \mathrm{c}$ & $466.83 \mathrm{c}$ \\
Plathymenia reticulata & $303.04 \mathrm{~d}$ & $312.03 \mathrm{~d}$ & $412.45 \mathrm{c}$ & $423.87 \mathrm{c}$ & $572.06 \mathrm{~b}$ & $700.97 \mathrm{a}$ \\
\hline
\end{tabular}

* The means followed by the same letter on the line do not differ statistically from each other by the Tukey test at the $5 \%$ probability level. CV\%: (S. terebinthifolius: 15.83; S. brasiliensis: 17.84; D. nigra: 13.63; C. speciosa: 10.79; C. peltophoroides: 11.17; P. reticulata: 11.76$)$.

The SLA of aroeira and braúna exposed to different levels of shading were compared. Data revealed that SLA values determined for both aroeira and braúna, which are both members of the Anacardiaceae family, were very similar (Table 1), and indicated that both plants similarly responded to light. Dalbergia nigra (Vell.) Fr. All. ex Benth. (jacarandá-da-bahia) leaf growth is shown in Figure 1C. SLAs determined using whole leaves of plants subjected to shading levels of $0 \%$ (full sunlight), 20, $40,60,80$ and $90 \%$, were $369.78,321.18,359.39$, $414.10,517.25$ and $635.10 \mathrm{~cm}^{2} \mathrm{~g}^{-1}$, respectively. Similar trends in which values increased linearly from 20 to $90 \%$ shading in were also observed when the SLAs of new and expanded leaflets were determined.
The SLA of the jacaranda-da-bahia increased concomitantly as shading levels increased, which indicated that the plant is very well adapted to high levels of shading. This is a typical characteristic of late secondary species (Pacheco, Pereira, Silva, \& Alvarenga, 2013). This finding, which was not observed in either aroeira or braúna species, should be taken into account when jacardanda-da-bahia is used for reforestation. When observed the initial shading, these were not as representative for the jacaranda-da-bahia, as they remained with an area inferior to the treatment in full sunlight. The SLA determined for whole leaves of plants exposed to $20 \%$ shade was $321.18 \mathrm{~cm}^{2} \mathrm{~g}^{-1}$, while that of plants exposed to $90 \%$ shade was $635.10 \mathrm{~cm}^{2} \mathrm{~g}^{-1}$. Thus, an SLA increase of approximately $51 \%$ was observed 
in leaves exposed to 90 vs. $20 \%$ shade. These results confirm that jacarandá-da-bahia species should not be one of the first introduced to regenerate forests. The species is classified as late secondary, since it tolerates little to medium levels of shade (Carvalho, 1994).

Average SLA values determined for jacarandada-bahia did not statistically vary when entire leaves and leaflets were used to generate data (data not shown). However, statistical differences were observed when mean SLAs of plants exposed to varied levels of shading were compared (Table 1). Rêgo and Possamai (2003) observed that jacarandada-bahia seedlings exposed to a moderate degree shading (44\% and 64\%) had larger leaves. These findings were not observed in this study, since the largest mean leaf area occurred in plants subjected to $90 \%$ shade. The authors also emphasized that planting in the field should be carried out in slightly shaded areas, in order to maintain seedling stem quality and maximize growth.

SLA of Chorisia speciosa A.St.-Hil (paineira) species are shown in Figure 1D. Findings indicated that SLA increased as level of shading increased. The only exception to this trend was observed in plants exposed to $40 \%$ shade. These plants had slightly lower leaflet and whole leaf SLA values than those which were determined for plants exposed to $20 \%$ shade. Leaf areas of whole leaves, expanded leaflets and emerging leaflets of plants exposed increasing levels of shading increased 203.77, 288.47 and $176.83 \mathrm{~cm}^{2} \mathrm{~g}^{-1}$, which represented 46,40 and $52 \%$ increases, respectively.

Like findings previously described, the leaf areas of paineira species did not statistically differ when values determined using whole leaves and leaflets were compared. However, leaf area did differ when levels of shading were compared (data not shown). In Table 1, the relationship between average SLA and shading level is shown. SLA values determined for plants exposed to 60 and $80 \%$ did not differ, and neither did values determined for plants exposed to 20 and $40 \%$ shade. However, exposure to $90 \%$ shade increased leaf area in the species in a manner similar to that which was observed for other species described. According to Campos and Uchida (2002), low light intensity is associated with increased SLA. This allows plants to maximize the collection of minimally available light and, thus, to enhance physiological functioning and survival.

Assessment of the SLA of Caesalpinia peltophoroides Benth (sibipiruna) revealed trends that were similar to those observed for paineira species. However, for plants were exposed to $40 \%$ shade, an increase in the SLA of new leaflets relative to those exposed to $60 \%$ shade was observed (Figure 1E). The increase of SLA for whole leaves, expanded leaflets and new leaflets that occurred in plants exposed to $90 \%$ shade relative to full sunlight was 229.29, 163.99 and $190.82 \mathrm{~cm}^{2} \mathrm{~g}^{-1}$, respectively, which corresponded to increases of 53, 64 and 58\%, respectively. As shown in Table 1, SLA values determined for plant leaves exposed to different levels of shade statistically differed, and differences were most distinct when leaves exposed to $90 \%$ shade were compared to those exposed to unobstructed sunlight.

Results determined from the assessment of the leafarea of Plathymenia reticulata Benth(vinhático), are shown in Figure 1F. Relative to leaflets exposed to unobstructed sunlight, those exposed to $20 \%$ shade displayed slightly reduced SLA. Similarly, expanded leaflets exposed to $60 \%$ shade, relative to $40 \%$ shade, displayed a slight reduction in mean SLA. Trends observed for the species were similar to those of other species assessed.

The SLAs of whole leaves, expanded leaflets and new leaflets of vinhático exposed to $90 \%$ shading differed from those exposed to unobstructed sunlight by $360.04,448.33$ and $384.89 \mathrm{~cm}^{2} . \mathrm{g}^{-1}$, respectively. This represented a 47,38 and $45 \%$ change in area, respectively. A comparison of SLA values determined for whole leaves and leaflets exposed to the same levels of shade revealed that values did not significantly differ (data not shown). However, when analyzing differences between the SLAs of 
leaves exposed to different levels of shade, values were statistically distinct (Table 1). SLA values determined for plants exposed to 40 and $60 \%$ shade did not differ. SLA values determined for vinhático exposed to unobstructed sunlight and 20\% shading also did not differ, which indicated that these differences in sun exposure do not influence SLA.

The data presented in Table 2 describe findings determined for all species exposed to each level of shading. The assessment was performed since there was no difference observed between measurements of the whole leaf and leaflets of species. In this analysis, the pioneer species aroeira and braúna, which belong to the same family, stood out. Findings of each species were similar, and no statistical differences among species were observed. When jacarandá-da-bahia, sibipiruna and vinhático were exposed to $20 \%$ shade, similar SLA values were produced. However, when the species were exposed to different degrees of shading, SLA values did differ. In fact, only jacarandá and sibipiruna had the same SLA values when plants were exposed to $40 \%$ shade, and only vinhático and jacarandá had the same SLA values when plants were exposed to $60 \%$ shade. When plants were exposed to $90 \%$ shade, the SLA of paineira was similar to those of braúna and aroeira.

\section{Table 2}

Averages of the specific leaf area (SLA) of the six forest species in relation to the different levels of shading

\begin{tabular}{lcccccc}
\hline \multirow{2}{*}{ SLA species } & \multicolumn{5}{c}{ Shading levels } \\
\cline { 2 - 7 } & $0 \%$ & $20 \%$ & $40 \%$ & $60 \%$ & $80 \%$ & $90 \%$ \\
\hline Schinus terebinthifolius & $127.40 \mathrm{~d}$ & $153.43 \mathrm{c}$ & $158.49 \mathrm{~d}$ & $202.87 \mathrm{~d}$ & $270.08 \mathrm{e}$ & $372.06 \mathrm{~d}$ \\
Schinopsis brasiliensis & $142.30 \mathrm{~cd}$ & $157.76 \mathrm{c}$ & $168.39 \mathrm{~d}$ & $229.72 \mathrm{~cd}$ & $264.99 \mathrm{e}$ & $399.32 \mathrm{~d}$ \\
Dalbergia nigra & $392.54 \mathrm{a}$ & $314.84 \mathrm{a}$ & $348.50 \mathrm{~b}$ & $418.88 \mathrm{a}$ & $515.47 \mathrm{~b}$ & $651.43 \mathrm{~b}$ \\
Chorisia speciosa & $185.15 \mathrm{c}$ & $217.94 \mathrm{~b}$ & $213.86 \mathrm{c}$ & $256.03 \mathrm{c}$ & $340.17 \mathrm{~d}$ & $377.34 \mathrm{~d}$ \\
Caesalpinia peltophoroides & $272.13 \mathrm{e}$ & $306.16 \mathrm{de}$ & $344.61 \mathrm{~cd}$ & $360.67 \mathrm{c}$ & $410.40 \mathrm{~b}$ & $466.83 \mathrm{a}$ \\
Plathymenia reticulata & $303.04 \mathrm{~b}$ & $312.03 \mathrm{a}$ & $412.45 \mathrm{a}$ & $423.87 \mathrm{a}$ & $572.06 \mathrm{a}$ & $700.97 \mathrm{a}$ \\
\hline \multicolumn{1}{c}{ CV\% } & 23.79 & 12.12 & 15.16 & 12.04 & 12.75 & 8.73 \\
\hline
\end{tabular}

* The means followed by the same letter in the column do not differ statistically from each other by the Tukey test at the level of $5 \%$ probability.

Data within Table 3 revealed that as degree of shading increased, SLA tended to increase, as expected. However, despite the fact that they are heliophilous, some species such as aroeira and braúna, did not have SLA values that significantly increased as degree of shading increased, relative to other species (Table 4). This may have been a result of insufficient light resources. Greenhouse conditions at each level of shading were, however, the same for all species, as shown in Table 4. This finding is in accordance with work performed by Ortega, Almeida, Maia and Angelo (2006). The authors reported Psidium cattleianum, which is also a heliophile, did not display significantly increased leaf area as a result of increased degree of shading.

The data shown in Table 3 demonstrate that in unobscured sunlight and when plants were subjected to $20 \%$ shade, no differences between species were observed. Additionally, data revealed that SLA values determined for jacarandá-da-bahia and vinhático did not differ; and neither did SLA values of aroeira and braúna. Data presented in Table 4 showed that leaf area was significantly affected by increasing the degree of shading, and that exposure to $90 \%$ shade, for most forest species, resulted in the greatest SLA values. 
Table 3

Comparison of the specific leaf area (SLA) of all forest species in each shading treatment

\begin{tabular}{cccccccc}
\hline & \multicolumn{7}{c}{ Shading levels } \\
\cline { 2 - 7 } & $0 \%$ & $20 \%$ & $40 \%$ & $60 \%$ & $80 \%$ & $90 \%$ & $494.66 \mathrm{a}$ \\
\hline SLA & $237.09 \mathrm{e}$ & $243.70 \mathrm{e}$ & $274.38 \mathrm{~d}$ & $315.34 \mathrm{c}$ & $395.53 \mathrm{~b}$ & 4 \\
\hline
\end{tabular}

* The means followed by the same letter on the line do not differ statistically from each other by the Tukey test at the $5 \%$ probability level. $\mathrm{CV} \%-\mathrm{a}=11.59$.

Table 4

Comparison of the specific leaf area (SLA) of all shading in each forest species

\begin{tabular}{ccccccc}
\hline & \multicolumn{9}{c}{ Forest species } \\
\cline { 2 - 7 } & aroeira & braúna & jacarandá & paineira & sibipiruna & vinhático \\
\hline SLA & $214.05 \mathrm{~d}$ & $227.08 \mathrm{~d}$ & $440.28 \mathrm{a}$ & $265.08 \mathrm{c}$ & $360.14 \mathrm{~b}$ & $454.07 \mathrm{a}$ \\
\hline
\end{tabular}

* The means followed by the same letter on the line do not differ statistically from each other by the Tukey test at the level of $5 \%$ probability. $\mathrm{CV} \%-\mathrm{b}=13.82$.

It is worth mentioning that light is not the only environmental factor capable of influencing leaf characteristics, since temperature, soil characteristics and water availability have also been shown to affect leaf area (Boeger et al., 2006). SLA relates is a measure of the leaf surface relative to its own weight, meaning that it represents area per gram of leaf tissue, and indicates the way in which leaf biomass per unit leaf area is allocated (Grisi et al., 2011). Analyses presented here demonstrated that there was no difference between values produced using either whole leaves or isolated leaflets. Studies with other species with and without compound leaves, should be carried to ensure the reliability of each type of SLA measurement method.

\section{Conclusion}

Leaves of Schinus terebinthifolius Raddi (aroeira), Schinopsis brasiliensis Engl. (braúna), Dalbergia nigra (Vell.) Fr. All. ex Benth. (jacarandada-bahia), Chorisia speciosa A. St.-Hil (paineira), Caesalpinia peltophoroides Benth (sibipiruna) and Plathymenia reticulata Benth (vinhático) that were measured using both whole leaf and individual leaflets produced nearly identical SLA values. Further, SLA varied according to shading level. These results indicate that for these forest species the entire leaf may be used to generate leaf area measurements, and it is not necessary to measure SLA using detached leaflets, which enhances the speed and practicality of performing analyses.

\section{Acknowledgments}

This study was financed in part by the Coordenação de Aperfeiçoamento de Pessoal de Nível Superior- Brasil (CAPES) - Finance Code 001, Conselho Nacional de Desenvolvimento Científico e Tecnológico (CNPq) and Fundação Carlos Chagas Filho de Amparo à Pesquisa do Estado do Rio de Janeiro (FAPERJ).

\section{References}

Azevedo, C. F., Quirino, Z. G. M., \& Bruno, R. L. A. (2015). Estudo farmacobotânico das partes aéreas da pimenta brasileira (Schinus terebinthifolius Raddi). Revista Brasileira de Plantas Medicinais, 17(1), 2635. doi: 10.1590/1983-084X/11_090 
Boeger, M. R. T., Kaehler, M., Melo, J. C. F. Jr., Gomes, M. Z., Oliveira, L. S., Chaves, M. C. R., \& Schottz, E. S. (2006). Estrutura foliar de seis espécies do subosque de um remanescente de floresta ombrófila mista. Hoehnea, 33(4), 521-531. Recuperado de https:// www.researchgate.net/publication/ 270591068

Câmara, C. A., \& Endres, L. (2008). Desenvolvimento de mudas de duas espécies arbóreas: Mimosa Caesalpiniifolia Benth. e Sterculia Foetida L. sob diferentes níveis de sombreamento em viveiro. Floresta, 38(1), 43-51. doi: 10.5380/rf.v38i1.11026

Campos, M. A. A., \& Uchida, T. (2002). Influência do sombreamento em crescimento de mudas de três espécies amazônicas. Pesquisa Agropecuária Brasileira, 37(3), 281-288. doi: 10.1590/S0100204X2002000300008

Carvalho, P. E. R. (1994). Espécies florestais brasileiras: recomendações silviculturais, potencialidades e uso da madeira. Colombo: EMBRAPA Florestas. Recuperado de https://www.bdpa.cnptia.embrapa. $\mathrm{br} /$ consulta $/$ busca? $\mathrm{b}=$ pc\&id $=293953$ \&biblioteca $=\mathrm{V}$ azio\&busca $=$ assunto:Semente $\&$ qFacets $=$ assunto:Se mente $\&$ sort $=\&$ paginacao $=$ t\&paginaAtual $=300$

Chazdon, R. L., \& Uriarte, M. (2016). Natural regeneration in the context of large-scale forest and landscape restoration in the tropics. Biotropica, 48(6), 709-715. doi: 10.1111/btp.12409

Dong, T., Liu, J., Shang, J., Qian, B., Ma, B., Kovacs, J. M.,.. Shi, Y. (2019) Assessment of red-edge vegetation indices for crop leaf area index estimation. Remote Sensing of Environment, 222(1), 133-143. doi: $0.1016 /$ j.rse.2018.12.032

Dutra, T. R., Grazziotti, P. H., Santana, R. C., \& Massad, M. D. (2012). Desenvolvimento inicial de mudas de copaíba sob diferentes níveis de sombreamento e substratos. Revista Ciência Agronômica, 43(2), 321329. Recuperado de http://www.scielo.br/pdf/rca/ v43n2/a15v43n2.pdf

Gao, M., Van der Heijden, G. W., Vos, J., Eveleens, B. A., \& Marcelis, L. F. M. (2012). Estimation of leaf area for largescale phenotyping and modeling of rose genotypes. Scientia Horticulturae, 138(1), 227-234. doi: $10.1016 /$ j.scienta.2012.02.014

Gris, D., \& Temponi, L. G. (2017). Similaridade florística entre trechos de floresta estacional semidecidual do corredor de biodiversidade Santa Maria - Pr. Ciência Florestal, 27(3), 1069-1081. doi: 10.5902/ 1980509828682
Grisi, F. A., Angelo, A. C., Boeger, M. R. T., Leitão, C. A. E., Galvão, S. F., \& Wendling, I. (2011). Morfoanatomia foliar em mudas de Schinus Terebinthifolius sob diferentes níveis de saturação hídrica. Floresta, 41(4), 881-894. doi: doi: 10.5380/ rf.v41i4.25351.

Klich, M. G. (2000). Leaf variations in Elaeagnus angustifolia related to environmental heterogeneity. Environmental and Experimental Botany, 44(3), 171-183. doi: 10.1016/S0098-8472(00)00056-3

Leite, E. J. (2002). State-of-knowledge on Myracrodruon urundeuva Fr. Allemão (Anacardiaceae) for genetic conservation in Brazil. Perspectives in Plant Ecology, Evolution and Systematics, 5(3), 193-206. doi: 10.1078/1433-8319-00034

Liang, W., Kirk, K. R., \& Greene, J. K. (2018). Estimation of soybean leaf area, edge, and defoliation using color image analysis. Computers and Electronics in Agriculture, 150(1), 41-51. doi: 1016/j.compag. 2018.03.021

Meio Ambiente - Instituto de Química - Universidade Federal do Rio de Janeiro (2016). Projeto I-Flora: Estudo, análise e registro da biodiversidade da Mata Atlântica e de seu potencial científico. Rio de Janeiro: UFRJ. Recuperado de https://www.Iq.Ufrj. $\mathrm{Br} /$ Meioambiente

Monteiro, P. P. M., \& Ramos, F. A. (1997). Beneficiamento e quebra de dormência de sementes em cinco espécies florestais do cerrado. Revista Árvore, 21(2), 169-174. Recuperado de https://books.google. com. br/

Moraes, L., Santos, R. K., Zeizer, T. W., \& Krupek, R. A. (2013). Avaliação da área foliar a partir de medidas lineares simples de cinco espécies vegetais sob diferentes condições de luminosidade. Revista Brasileira de Biociências, 11(4), 381-387. Recuperado de http://www.ufrgs.br/seerbio/ojs/ index. php/ rbb/article/view/2413

Oliveira, L. S. B., Marangon, L. C., Feliciano, A. L. P., Oliveira Cardoso, M., Lima, A. S., Santos, W. B., \& Silva, V. F. (2012). Structure of the woody component of an atlantic forest fragment, Pe. Semina: Ciências Agrárias, 33(1), 203-212. doi: 10.5433/1679-0359

Ortega, A. R., Almeida, L. S., Maia, N., \& Angelo, A. C. (2006). Avaliação do crescimento de mudas de Psidium Cattleianum Sabine a diferentes níveis de sombreamento em viveiro. Cerne, 12(3), 300-308. Recuperado de http://www.cerne.ufla.br/site/index. php/CERNE/article/download/392/335 
Ottermanns, R., Hopp, P. W., Guschal, M., Santos, P. G., Meyer, S., \& Roß-Nickoll, M. (2011). Causal relationship between leaf litter beetle communities and regeneration patterns of vegetation in the atlantic rainforest of southern Brazil (Mata Atlântica). Ecological Complexity: Special Section: Complexity of Coupled Human and Natural Systems, 8(4), 299309. doi: 10.1016/j.ecocom.2011.06.001

Pacheco, F. V., Pereira, C. R., Silva, R. L., \& Alvarenga, I. C. A. (2013). Crescimento inicial de Dalbergia nigra (Vell.) Allemão ex. Benth. (Fabaceae) e Chorisia speciosa A.St.-Hil (Malvaceae) sob diferentes níveis de sombreamento. Revista Árvore, 37(5), 945-953. doi: 10.1590/S0100-67622013000500017

Permanhani, M., Vasconcellos, M. A. S., Souza, R. T., \& Martelleto, L. A. P. (2014). Estimativa de área foliar da videira 'niagara rosada' conduzida em sistema de latada, Região Norte Fluminense. Revista Brasileira de Fruticultura, 36(4), 1034-1040. doi: 10.1590/0100-2945-314/13
Rêgo, G. M., \& Possamai, E. (2003). Jacarandá-DaBahia (Dalbergia Nigra Vellozo) Leguminoseae - Papilionoideae: produção de mudas. Colombo: EMBRAPA Florestas. (Comunicado Técnico, 106). Recuperado de https://www.embrapa.br/buscade-publicacoes/-/publicacao/309652/jacarandada-bahia-dalbergia-nigra-vellozo-leguminoseaepapilionoidae-producao-de-mudas

Roweder, C., Nascimento, M. S., \& Silva, J. B. (2015). Produção de mudas de mogno sob diferentes substratos e níveis de luminosidade. Journal of Bioenergy and Food Science, 2(3), 91-97. doi: 10. 18607/jbfs.v2.i.3.39

Scalon, S. P. Q., Scalon, H., Fo., \& Masetto, T. E. (2012). Germinação e desenvolvimento inicial de plântulas de aroeira (Myracrodruon urundeuva). Cerne, 18(4), 533-539. doi: 10.1590/S0104-776020120004000 02

Wang, Y., Jin, G., Shi, B., \& Liu, Z. (2019). Empirical models for measuring the leaf area and leaf mass across growing periods in broadleaf species with two life histories. Ecological Indicators, 102(1), 289301. doi: 10.1016/j.ecolind.2019.02.041 
